\title{
El final del bandoler: aproximació a la literatura de patíbul de la Corona d'Aragó
}

\author{
The end of the bandit: an approach to gallows literature in Crown of \\ Aragon
}

\author{
Alejandro Llinares Planells \\ allinaresplanells0@gmail.com \\ Universitat de València
}

Resum: Durant l'època moderna s'imprimiren nombrosos plecs de cordell relacionats amb el bandolerisme en els territoris de la Corona d'Aragó. Una part important d'aquests textos populars és el final que rep el protagonista de la història, que normalment solia acabar al patibul. Per aqueixa raó, el present article posa l'accent en un tema poc tractat fins al moment, com són les execucions públiques en aquest tipus de relats literaris. En aquestes pàgines s'estudia, per una banda, el ritual punitiu que sofria el reu quan anava a ser executat: formes d'execució, turments, penes corporals o la intenció que tenien els pamflets que s'imprimien. Per altra, es comparen documents judicials amb els plecs de cordell, per a demostrar que podria existir un traspàs d’informació entre els òrgans de justícia i les persones encarregades d'escriure els plecs.

Paraules clau: Bandoler, literatura popular, patibul, pena capital, literatura de canya i cordell

Abstract: During the modern era, numerous cord folders related to banditry were printed in the territories of the Crown of Aragon. A relevant part of these popular fiction tales is the end that the main characters of these stories usually suffer: being hanged in the gallows. This paper focuses on a little-known topic so far, such as public executions in literary texts. In these pages, I'll discuss the punitive ritual suffered by the criminal when he was going to be executed: forms of execution; torture; and the social and cultural intentionality theses chapbooks had. Furthermore, judicial documents will be compared with chapbooks in order to show that there could be a transfer of information between law institutions and the autors of these popular poems..

Keywords: Bandit, popular literature, gallows, death penalty, chapbook 


\section{Alejandro Llinares Planells. El final del bandoler: aproximació a la literatura de patíbul de la}

Corona d'Aragó

En España, como en Francia, la ejecución de un criminal famoso da lugar a innumerables coplas de ingeniosos versos que se venden por las calles. Dase en ellas un relato completo de las circunstancias que han acompañado al crimen y la reseña de la fúnebre ceremonia. (Davillier 1991: 27).

\section{Introducció}

Durant l'època moderna s'imprimiren plecs de cordell de distintes temàtiques: religiosos, sobre atacs de pirates, humorístics, lluita contra el turc, relacionats amb la reialesa o successos paranormals. Però la temàtica bandolera fou un dels temes més recurrents des dels principis del segle XVI fins a ben entrat el segle XIX. El final del període delictiu o de la vida de bandoler és una part cabdal dins dels esquemes dels plecs de bandolers durant tota l'època moderna. Com bé comentava Joan Fuster, els bandolers literaris havien d'acabar morint, i, si era damunt del patíbul, millor encara (Fuster 1977: 92). La població de l'antic règim que llegia els relats de bandolers, persones de distintes capes socials (Gomis 2015), podia sentir-se identificada amb els protagonistes de les històries, sobretot en els romanços de guapos, ${ }^{1}$ però els bandits que havien incomplit la llei havien de morir, i la gent ho veia normal. Aquest esquema contrasta amb la literatura romàntica del segle XIX, on es crea el mite del bandit generós i patriota, per influència del nacionalisme espanyol (Andreu 2016: 90-95). Així doncs, si aquest personatge vuitcentista acabava morint al patíbul, solia ser sinònim d'una injustícia, inclús es feien crítiques a la justícia com en el relat de Jaume el Barbut, on es narra que el bandit és enganyat per les autoritats, perquè ja havia estat indultat pels seus serveis a la causa absolutista. ${ }^{2}$

Aquest tipus d'escrits literaris en què es representen els delictes i la mort del bandit, en molts casos podien jugar la funció de literatura de patíbul, terme encunyat per Hans-Jürgen Lüberink, perquè estigueren inspirats en accions reals, seguiren el ritual punitiu establert i podien ser venuts en el mateix moment en què el reu anava a ser ajusticiat, com a relat literari, informatiu i moralitzant (Lübebrink 1982: 284-301). És ben conegut el gravat de William Hogarth, The idle Prentice rentice Executed at Tyburn, de 1747, que mostra una execució pública on la gent acudeix en massa per poder presenciar-la. En l'escena principal, al costat del reu, en el carretó que el du a la forca, està representada una dona amb un xiquet en els braços que està pregonant la venda d'un imprés sobre la persona que van a executar.

1 El Diccionari defineix guapo en una de les seues accepcions com a: 'home que presumeix de valent; baralladís per ostentació', en Alcover-Moll, Diccionari Català-Valencià-Balear (en xarxa): http://dcvb.iecat.net/ (consultat el dia 4/12/2017). Aquest terme era del més utilitzat per referir-se als bandolers del segle XVIII.

2 Historia verdadera del famoso guerillero y bandido Jaime el Barbudo, o sea, el terror de la Sierra de Crevillente. Còpia digital en Cambridge Digital Library. 
Alejandro Llinares Planells. El final del bandoler: aproximació a la literatura de patíbul de la Corona d'Aragó

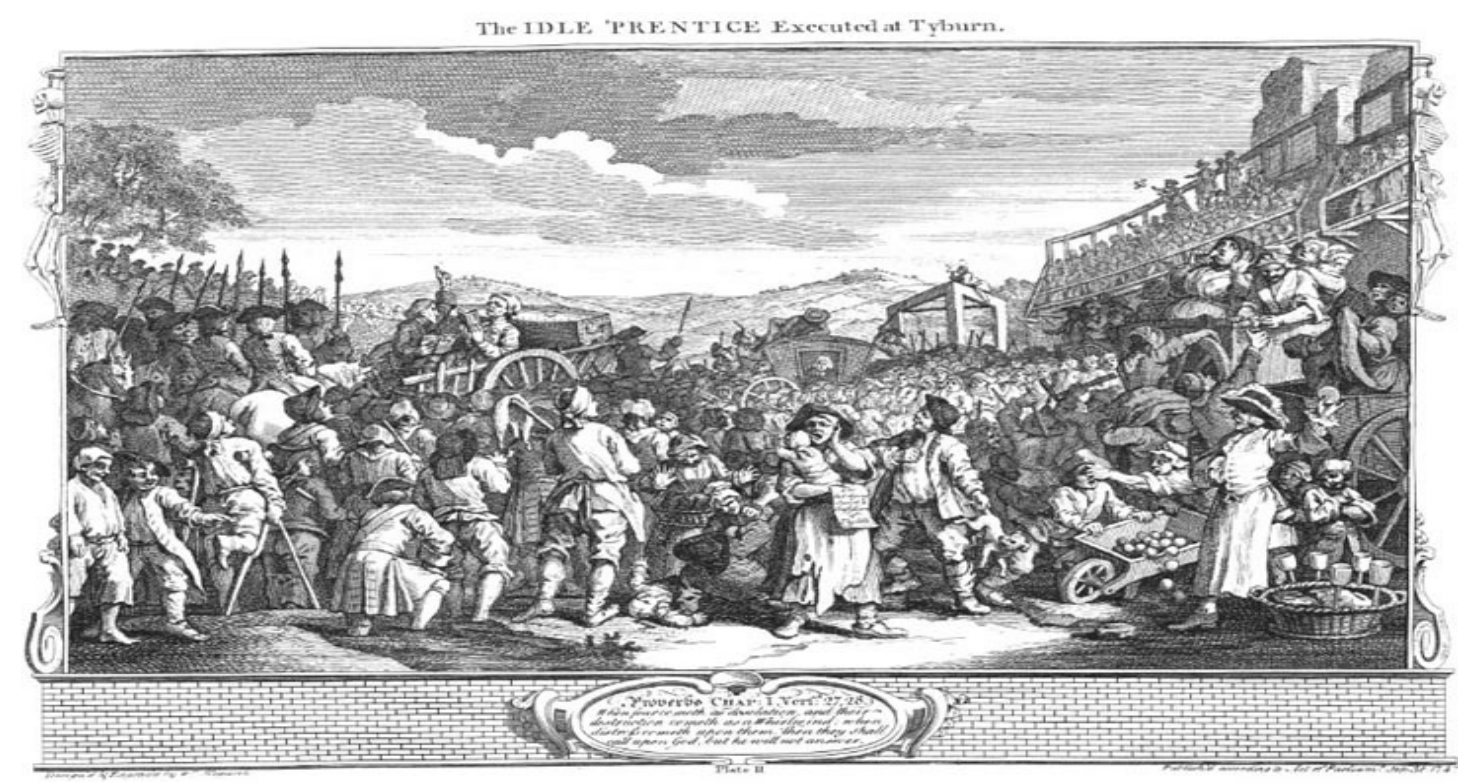

Fig 1: William Hogarth, The idle Prentice Executed at Tyburn, 1747, National Gallery of Art, Washington DC.

L'afluència massiva de públic era un bon lloc per vendre els impresos perquè tenien molt bona acceptació entre la gent, aleshores:

Cuando ocurría un crimen (...), ó adquiría fama algún bandido (...); cuando se cometía (...) algún asesinato ó era ajusticiado algún reo de importancia, el impresor llamaba á uno de los dos ó tres poetas que no tenían sobre qué caerse muertos y estaban á su devoción, les daba instrucciones detalladas respecto del romance que les encargaba (Nombela 1914:65).

Els Avisos de Pellicer, el 17 de maig 1644, es fan ressò de com un cec duia la notícia d'un ajusticiat: «En Valladolid han hecho justicia estos días de un cabo de vandoleros muy nombrado llamado Salgado. Murió muy arrepentido y de su muerte, conversión y delitos traen los ciegos una relación en verso.» (Civil 1989: 139)

Segons l'estudi de Lüsebrink, existiren dos gèneres principals de literatura de patíbul, és a dir, les «complainte criminales», que eren composicions musicals, en vers, sobre la vida delictiva dels reus, i la «relation», narració breu, en prosa, que donaven compte dels fets que havien dut als criminals al patíbul. Els dos tenien una finalitat moral, religiosa i utilitzaven alguna vegada un to satíric, encara que no exempts de crítica. L'autor alemany presta atenció als relats francesos, però diu que aquests tipus d'impresos eren abundants en molts països d'Europa, entre ells l'actual estat espanyol (Lübebrink 1982: 285-290). Agafant el relleu de Lüsebrink, l'historiador francés Pascal Bastien ha estudiat la literatura de patíbul francesa i també diferencia entre «complaintes» i «relations», però els dóna un paper important dins de la mateixa execució, on es veien molts d'aquests plecs. Els 
Alejandro Llinares Planells. El final del bandoler: aproximació a la literatura de patíbul de la Corona d'Aragó

impresos de França o d'Anglaterra agafen les últimes paraules dels condemnats, que constituïen el que es coneix com «testaments de mort», en els quals s'incloïen les paraules malsonants dels reus, les crítiques a la justícia, etc., que llegia el capellà en el moment de la mort i que podien qüestionar l'ordre establert (Bastien 2006: 25-56).

En la Corona d'Aragó trobem impresos pareguts, concretament en la Catalunya del segle XVI, com: Summa del testament de part dels bandolers de la companya de Moreu Palau, Cascavell y Camadall a sis de abril, 1573, ${ }^{3}$ o Testament y condesil y legats de Joanot, bandoler, y sos companyos, ${ }^{4}$ perquè són textos escrits en primera persona, on el bandit fa una mena de testament davant de notari abans de ser executat. Malgrat això, els testaments són ficticis, és a dir, difícilment serien les últimes paraules dels condemnats, perquè la finalitat que tenien era la de mostrar un penediment del reu i, sobretot, enaltir a les autoritats per capturar als criminals; i encara que el format i l'estructura són similars als relats francesos, no és exactament la mateixa tipologia de plec. Tot i no ser igual, és innegable que la literatura de cordell a nivell europeu tenia influències dels diferents països (Burke 2005), perquè molts quincallers tenien contactes amb l'estranger i més un territori com el català, que té frontera natural amb França.

\section{Les execucions}

Les execucions solien fer-se en els carrers i places més concorreguts de cada lloc, com la Plaça del Mercat, a València, o la Plaça del Rei, a Barcelona, normalment a migdia, procurant eludir els dies festius. En aquests llocs es posaven els cecs i els quincallers a vendre els seus materials. Però la literatura de patíbul no sols tenia la funció de divertir o informar a la gent: per una banda funcionava com una eina de propaganda en mans de les autoritats regnícoles o de la monarquia, i, per altra, llançava missatges amenaçadors o moralitzants a la població o als mateixos bandolers. Els cecs eren conscients que els seus escrits tenien una funció social, perquè els impresos de patíbul intentaven que la gent prengués exemple del que els passaria, si repetien accions com les del bandit que anava a ser executat. Per això, el 1751, els cecs de Madrid demanen al redactor del procés d'un reu «nos dé los asuntos de los delitos, arreglados a los autos seguidos contra dicho reo para hacer una relación en verso», per tal que l'escrit «sirva de escarmiento como ha sido uso y costumbre». ${ }^{5}$ (Gomis 2016:14) Per això, al final de molts plecs de guapos i valents, apareix el missatge d'advertència a la població, com el cas de Ramon Guardiola:

Escarmendad, pecadores

Ea a la enmienda, mortales

3 Biblioteca Nacional de Catalunya (BNC), Sig: 6- IV-39.

4 Obrer del Cançoner Popular de Catalunya (OCPC), Sèrie A, Materials Aguiló, carpeta A-15, II, núm. 9 bis. (Massot 1993:161).

5 Dades extretes del Archivo Histórico Nacional (AHN), Consejos, libro 1338, f.133.

SCRIPTA, Revista internacional de literatura i cultura medieval i moderna, núm. 10/desembre 2017/pp. 108-125 ISSN: 2340 - 4841 doi:10.7203/SCRIPTA.10.11085 
Alejandro Llinares Planells. El final del bandoler: aproximació a la literatura de patíbul de la Corona d'Aragó

Pidamos a Dios nos libre

de peligros semejantes

porque viviendo en su gracia

quando esta vida se acabe

consigamos su gloria

las delicias celestiales. ${ }^{6}$

En quasi tots els relats, el bandoler protagonista acaba mort, però molts no arriben al patíbul, sinó que moren en una emboscada o en una lluita. Per al present estudi hem analitzat el final que rep el bandit, en més de 40 plecs impresos des de principis del segle XVI fins a les primeres dècades del XIX que se centren en un bandoler concret per veure, grosso modo, com solen acabar en la literatura popular els bandolers de la Corona d'Aragó, com es pot observar en la gràfica: ${ }^{7}$

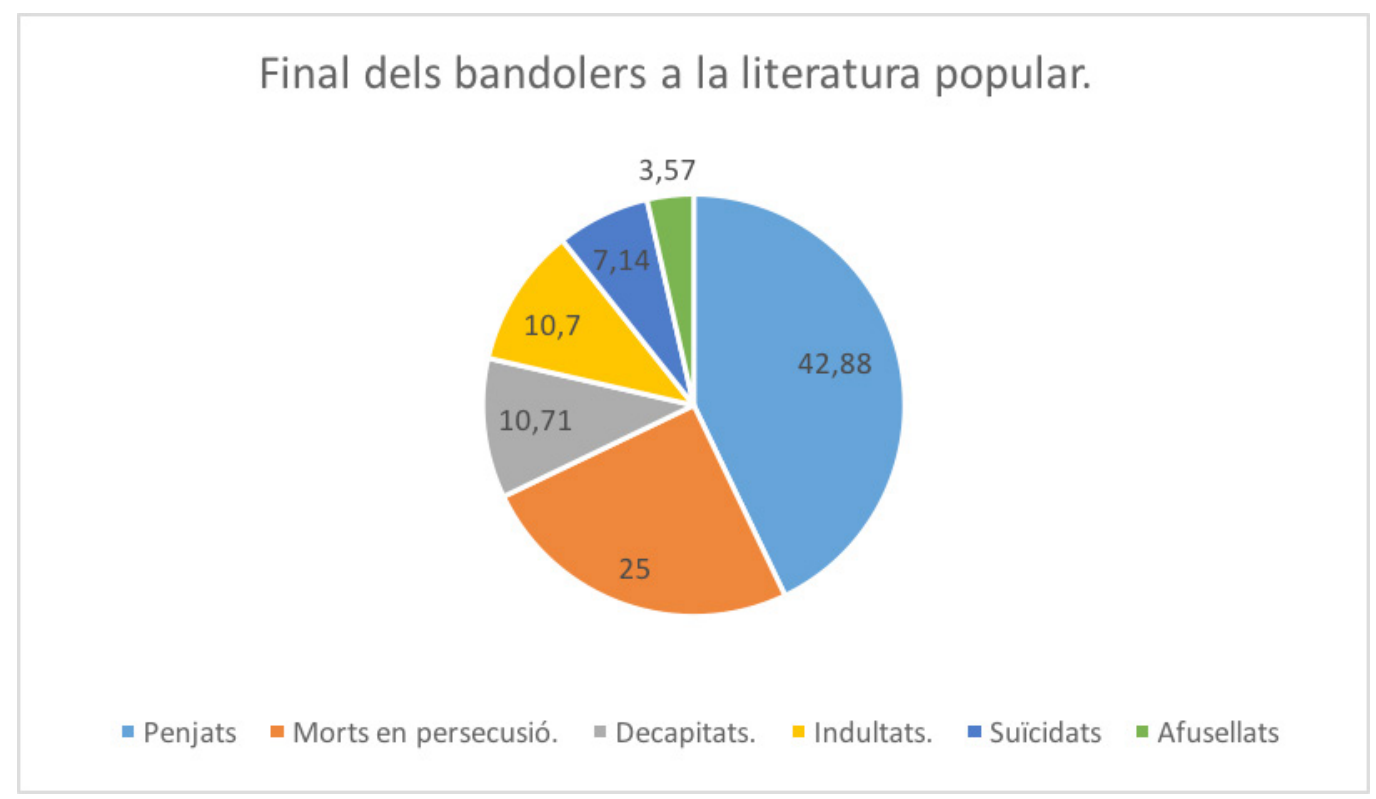

Fig 2: Gràfica d'elaboració pròpia amb les dades dels plecs.

\footnotetext{
6 Nueva Relación y curioso romance en que se da cuenta de los hechos, valentías y temerarios arrojos que confesó haber hecho un famoso capitan de vandoleros, llamado Ramon Guardiola, natural de la Vila de Valls, Reyno de Cataluña. Còpia Digital en Cambridge Digital Library.

7 Hem deixat fora d'aquest recull els impresos dels virreis o de la Unió del segle XVII, que no es centren en un bandoler concret, encara que puguen reproduir la sentència d'alguns bandits. Per a veure l'anàlisi de tots els impresos de bandolers coneguts fins al moment en els territoris de la Corona d'Aragó, vegeu Llinares (2017).
} 
Alejandro Llinares Planells. El final del bandoler: aproximació a la literatura de patíbul de la Corona d'Aragó

Com veiem, una àmplia majoria foren penjats, ja que era la pràctica més comuna d'executar els reus, com assenyalen Jorge Catalá i Pablo Pérez. ${ }^{8}$ (Catalá \& Pérez 1998: 212) La mort en persecució solia ser també normal, atés que molts bandolers eren assetjats, perquè s'havia emès una crida contra ells. Aleshores, quan es localitzava al cap de la quadrilla, podia resultat ferit de mort en el procés de la seua captura si emetia resistència. Al segle XVI, a Catalunya, alguns bandolers encara eren degollats, com Roca o els germans Poch, però aquest mètode d'execució en la centúria següent no solia ser aplicat als bandits, ja que aquests morien en la forca per regla general. A València, ser decapitat era un privilegi reservat a la noblesa: aquest tractament social davant la mort també apareix reflectit en els impresos populars: concretament, quan és condemnat a mort Josep Vallterra, que fou degollat per ser cavaller. (Catalá \& Pérez 1998: 237). En els impresos de Benet, aliat de Vallterra, es diu: «a un amigo le prendieron/ y por fin lo degollaron/ porque gozaba algun fuero» $i$ en un altre es diu que el decapiten «porque era el tal cavallero». ' L'afusellament, igual que el garrot vil, fou una pràctica generalitzada al llarg del segle XIX per donar mort als bandolers. Això es pot veure en la relació que fa Antonio Escudero dels bandolers executats en les primeres dècades del XIX, on quasi tots són afusellats.

Normalment els bandolers esgoten en la literatura les últimes possibilitats per viure, però en el cas dels germans Mogica, dos dels quatre germans «se volaron la cara» abans de ser agafats: no és una pràctica habitual en els plecs, però pot aparèixer, igual que va fer Juan Gea, detonant la pólvora quan se sentí encerclat per la justícia. ${ }^{10}$ Però no tots els bandolers acabaren morts: alguns foren indultats per anar a servir als terços d'Itàlia o Flandes, amb una finalitat militar i política, és a dir, s'aconseguia reclutar un soldat per un conflicte bèl lic i, a més, s'allunyava de la seua terra a un cap de quadrilla, com els passà a Benet, Centellas o Senent. En la literatura, el més normal és que el bandoler morís, perquè, com remarca Joan Fuster: «el bandoler, amnistiat, s'incorporava als exercits de la monarquia. Això, o el patíbul. El bandit honorable no tenia més sortida. El lladre corrent tampoc». (Fuster 1977: 94). Si el bandoler era indultat, en la literatura apareix com una derrota del virrei davant la impossibilitat de capturar-lo, com el cas de Benet:

\footnotetext{
Y viendo que no podia

Prenderlo vivo, ni muerto

Le embió el Rey a un Castillo

$\mathrm{Y}$ a todos sus compañeros

A Napoles, que serviessen
}

\footnotetext{
8 Aquets historiadors comptabilitzen 802 execucions en la forca al llarg del XVII a València.

9 Relación de vida, hechos y hazañas del valente Matheo Benet Vicente... Còpia Digital en Cambridge Digital Library.

10 Romance nuevo del mas arrogante arrojo nunca visto, ni oido, que bizo un contravandista de pólvora llamada Juan Gea. I Triste y sensible relación en la que se da cuenta de la sentencia ejecutada en Barcelona el día 27 de septiembre de 1845, en las persones de doce bandidos. Còpia Digital en Cambridge Digital Library.
} 


\section{Alejandro Llinares Planells. El final del bandoler: aproximació a la literatura de patíbul de la Corona d'Aragó}

En el dos años y medio

Y que si el tiempo cumpliessen

El perdon tendrian cierto.

Els plecs de cordell de bandolers, des del segle XVI fins a les primeres dècades del segle XIX, experimentaren una evolució en l'estructura i en el tractament que rebia el protagonista (Llinares 2017: 40-169), aleshores la representació del ritual punitiu dels que moriren en mans de la justícia també ho feu, almenys des del punt de vista literari. Al llarg dels segles XVI i XVII els impresos se centraven molt més en un esdeveniment concret, per tant els detalls sobre la captura i l'execució del bandoler eren més abundants. Encara que molts malfactors foren morts en lluites i persecucions, pràcticament la totalitat dels bandits dels textos literaris van rebre penes corporals abans de morir i també post mortem.

Cal diferenciar entre el turment i la pena corporal perquè, mentre que el primer era un mitjà per tal que el reu confessàs, la segona era un càstig establert, part de la sentència judicial, pels delictes que havia comés. Normalment el turment no sol aparèixer amb molts detalls en els impresos, més enllà d'una petita referència, com el cas del relat d'Antoni Roca: «molt pres lo van despullar/ y a la presó lo tornaren/ la vesprada de Sanct Juan/ molt més pena li donaren/ que li fora un turment gran». ${ }^{11}$ No solen especificar-se els procediments i els mètodes del turment: com a molt es podria dir que era sever, com el cas de Serrallonga: «tant grandes tormentos fueron/ que el verdugo le dio/ que su cuerpo se afligio/ cuando las cuerdas pudieron». ${ }^{12}$ Ací ens fa entendre que Joan Sala va sofrir estirament dels membres amb cordes per tal que confessàs, però, normalment, en els impresos sols apareix si el reu, després del turment, ha confessat o no, i en pràcticament la totalitat dels casos el reu acaba confessant: «declaré todas las cosas/ que en mi memòria se hallavan», deia Francesc Esbert, després del turment; sols Tocason resistí els mètodes de tortura sense obrir la boca.

Les penes corporals, que formen part de la sentència normalment, sí que solen especificar-se en el relat, sobretot en els del XVI i XVII, que descriuen el ritual des que el bandit ix de la presó fins la seua mort. Les execucions anaven precedides normalment d'un passeig del reu pel carrers, per tal que sofrira vergonya pública (Tomás y Valiente 1969: 386); seguidament era assotat i, mentre recorria el trajecte cap al patíbul, el reu patia diverses penes com «l'atenallement» (ferro calent sobre el cos), «axorallament» (amputació d'orelles), etc. Aquestes eren les més comunes, però també apareixen als impresos populars les amputacions de punys i de nas. El cas de Joanot Poch és ben il lustratiu:

11 Cobles fetes ara novament sobre la justícia i cruel mort d'Antoni Roca, escandalitzador de tota Catalunya $i$ de Sebastià Corts, son companyó (Aguiló 1900: 345-348).

12 Xacara y relación verdadera de los hechos y prisión del famoso bandolero Sierrallonga. (Givanel 1945: 1591592). 


\title{
Alejandro Llinares Planells. El final del bandoler: aproximació a la literatura de patíbul de la
} Corona d'Aragó

\author{
Junt ab la Real Audencia \\ Tot primer sia acotat \\ Y desorallat al lloch \\ Per los mals mes aflegir \\ (...) Posat en un carretó \\ Ab copa de foch encés \\ Ab tenalles de foch \\ Lo faran molt ben patir \\ (...) Mes havent per fer errades \\ Manado real consell \\ Que ses mans sien llevades \\ Y cremades devant ell \\ Y apres en lo tal lloch \\ Escorterat ses detenir.
}

Aquest tipus de penes sols apareixen en els textos catalans, perquè només al Principat comptem amb plecs de bandoler del segle XVI i principis del XVII, però aquestes eren habituals també a la ciutat de València en temps de Ferran el Catòlic. Emilia Salvador ha pogut constatar que les amputacions d'orelles i de punys, i també els assots, solien practicar-se de manera habitual als condemnats a mort i eren executades pel botxí o morro de vaques, com era conegut al cap i casal, que solia cobrar unes quotes, depenent de les penes que executava: per exemple, llevar les orelles costava «5 sous i 6 diners per orella» (Salvador 1996: 263-280).

Una vegada mort, en pràcticament la totalitat dels impresos, el reu era esquarterat i el cap posat en un lloc visible de la ciutat. A València, normalment en les Torres de Serrans o en el poble del bandoler; i, a Barcelona, en el portal de Sant Antoni. Els membres del cos eren repartits pels camins on el reu havia fet algun delicte o, en el seu defecte, podien ser cremats o llançats al barranc del Carraixet (en el cas de València, com es feu amb Martín Muñoz «mandant que muera ahorcado/ y que en Carraixet sea puesto/ que allí para los malvados»). ${ }^{13} \mathrm{La}$ finalitat era escarmentar la gent que veia les restes del bandit, i a més estava prohibit retirar-les fins a nova ordre. La història de Ramonet de Valls finalitza dient:

Luego le desquartizen

Cortaronle las orejas

Narizes y manos antes

Para escarmientos de tantos.

13 Famoso romance en que se da cuenta de los delitós, muertes y atrocidades del Valiente Martin Muñoz... Còpia Digital en Cambridge Digital Library. 
Alejandro Llinares Planells. El final del bandoler: aproximació a la literatura de patíbul de la Corona d'Aragó

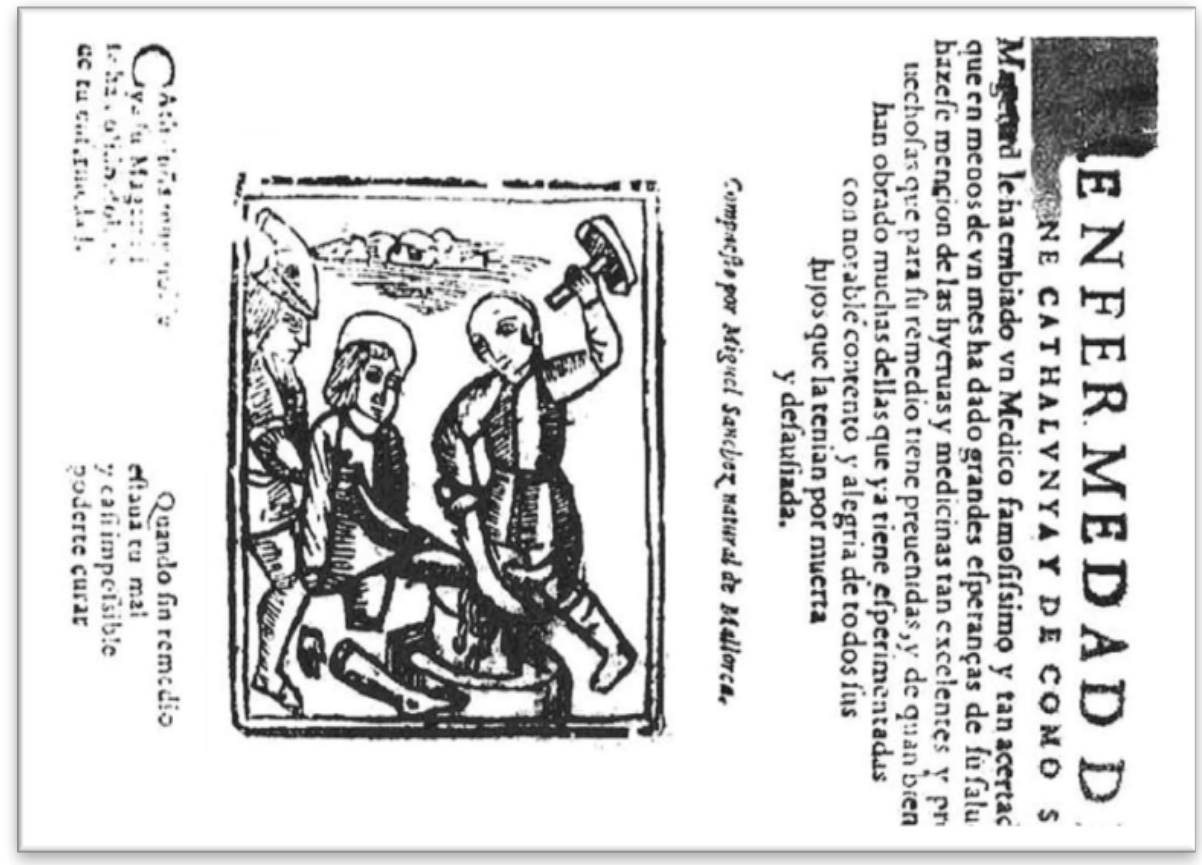

Fig 3: Gravat que representa l'esquarterament post portem del cos d'un bandoler del segle XVII. La enfermedad de la insigne Cathalunya y de como su Majestad le ha embiado un Médico famosissimo y tan acertado que en menos de un mes ha dado grandes esperanças de su salud haz̧ele mención de las hyervas y medicines... Esteve Liberos 1616. Còpia digital en Biblioteca Digital Siglo de Oro (Bidiso).

Una pena poc comuna, almenys per als bandolers, fou la cremació del cos en la foguera, però això fou el que li passà a les restes de Joan Escuder, perquè, a més de per bandit, fou també condemnat per hugonot; aleshores «molt grans foc ne varen fer/ restant fet cendra lo cos/ del maleit de n'Escuder». ${ }^{14}$ Un altre plec de final del XVI també relata una cremació: en aquest cas no es tracta d'un bandoler, sinó d'un home anomenat Joan Malet, que era un morisc català, aconseguidor de bruixes, que finalment fou condemnat per bruixeria i per estafar a la justícia ${ }^{15}$ (Blecua 1977: 48).

L'execució pública era un espectacle de masses i els impresos del XVI i XVII ho fan constar així. Per exemple, en una de les multitudinàries execucions promogudes pel virrei Alburberque, es diu que «Terrats y finestres/ carrers y cantons/ estaven de gent/ tots plens com un nou» $\mathrm{i}$ quan Serrallonga entrà en la ciutat comtal «molts grans festes/ per les finestres/ y per balcons/

14 Les Cobles dela presa y mort de Ioan Escuder fetes per Miquel Pelegri notari de la vila de Ripoll. OCPC, Sèrie A, Materials Aguiló, Carpeta A- 15, V. Vegeu la sentència a aquest bandoler als Dietaris de la Generalitat de Catalunya, vol II, pp.415-416.

15 Cobles ara nouament fetes sobre la mort den Malet. Feta en Barcelona als dos d Juliol. Any Mil e cinc cents quaranta e nou. 
Alejandro Llinares Planells. El final del bandoler: aproximació a la literatura de patíbul de la Corona d'Aragó

gent a montons/ per carrers, places/ mil baldalaces/ be podeu creure/ sols per veure/ entar lo Serra». ${ }^{16}$ Aquest espectacle era del gust de la gent i per això alguns dels plecs de cordell conviden a assistir a properes execucions:

\author{
Si voleu saber \\ Mes coses de nou \\ Partiu y vereu \\ Dimarts i dijous \\ Un altra enfilada \\ De caps y de colls \\ De aquí tenen fi \\ Mes llargues rahons ${ }^{17}$
}

En els impresos de guapos i valents, i en els del segle XIX també, es continua donant una gran importància a l'execució del bandoler, però, per ser un relat de la vida completa del bandit, molts se cenyien a relatar la seua sentència i execució, deixant de banda l'espectacle que suposava per a la població. En els relats del XVIII desapareixen les amputacions de mans, d'orelles o l'atenallament, encara que l'esquarterament continuava practicant-se post mortem. Malgrat que no és la nostra intenció entrar en el debat de la possible «humanització» o la fi de l'espectacle-execució, com apuntava Michel Foucault (1975), des del punt de vista literari sí que es dóna un canvi en el tractament de les execucions, és a dir, passen de ser espectacles amb penes cruels i doloroses abans i després de la mort del reu, a un càstig menys físic, amb un art de dolors més subtils, més silenciosos. ${ }^{18} \mathrm{En}$ els impresos de Jaume el Barbut, els Mogicas, Manuel Manchon, Pedro Andrés, entre altres, es descriuen els actes delictius dels bandolers i se'n reprodueix la sentència, entenent l'execució com un acte judicial i exemplaritzant, no com un càstig despietat. El més important era deixar constància que la justícia havia complit les seues funcions, i que, a més, havia aconseguit que el condemnat es penedira dels seus actes, per poder salvar l'ànima. En els impresos del XVIII i del XIX, quan el bandoler és executat, en la majoria del casos s'havia penedit dels seus pecats davant del confessor; la seua execució es mostrava aleshores com un acte exemplaritzant cap a la població, inclús podria el bandit ser vist com una mena de màrtir, com assenyala Santiago Cortés, perquè a l'hora de morir ja no era un pecador, ja que havia porgat les seues culpes i acceptava de bon grat l'execució per la vida que havia dut (Cortés 2007: 11-15). ${ }^{19}$ Per a Céline Gilard: «no se puede tachar

16 Relació certa y puntual de la bandolina. Morts, robos, hazanyes y valenties y presa, sentencia y castich del famós y valent bandoler cap de quadrilla Ioan Sala y Serrallonga, OCPC, Sèrie A, Materials Aguiló, carpeta A-15, XI, núm. 3.

17 Relació verdadera de la transformació de Catalunya y immemorial justícia de lladres y bandolers... (Amades 1995: 24-32).

18 Foucault estableix el final del que ell anomena «suplicios» amb l'aparició de la il lustració i l'alleujament de les lleis penals. Aquesta tesi ha segut revisada, entre d'altres per Bastien, que afirma que això és un procés gradual i ja al llarg del segle XVI es pot veure una rebaixa en algunes penes respecte a anys anteriors.

19 Aquest investigador compara la mort dels bandits amb la dels sants, i observa que encara que a priori són figures antagòniques, el bandoler que es penedeix i accepta la mort per la vida que havia dut no estava tan lluny de la figura del

SCRIPTA, Revista internacional de literatura i cultura medieval i moderna, núm. 10/desembre 2017/pp. 108-125 ISSN: 2340 - 4841 doi:10.7203/SCRIPTA.10.11085 
Alejandro Llinares Planells. El final del bandoler: aproximació a la literatura de patíbul de la Corona d'Aragó

de inmoral al público del cordel cuando celebra a héroes que transgredieron el orden establecido, pues necesitan, para amarlos plenamente, su arrepentimiento o su sumisión al poder»; per tant el penediment del bandoler és una part important en la literatura de patíbul (Gilard 2000: 92).

\section{Similitud entre la documentació judicial i els plecs de cordell}

La literatura de patíbul tenia èxit de vendes i per això arribà a suposar un subgènere dins de la literatura popular. Per aquell motiu, quan al 1767 Carles III emeté un decret per a prohibir els romanços de cec, feia especial incidència en las «coplas de ajusticiados». De la mateixa manera, a la Hermandad de Nuestra Señora de la Visitación d'invidents de Madrid se li concedí al 1748 «el monopolio de venta de relaciones de los reos ajusticiados en esta corte» (Gomis 2016: 13). Els cecs i venedors de plecs solien demanar documentació judicial als òrgans de justícia pertinents per a redactar el relat. Això passaria en diferents llocs de la Monarquia Hispànica, però en el cas de Madrid, com la confraria de cecs tenia el monopoli exclusiu d'aquest tipus d'impresos, està molt més estudiat, en tant que els invidents enviaven cartes a la justícia perquè «se digne a mandar que el relator de la causa del reo castigado hoy en esta corte entregue, como es uso y costumbre, los extractos de ella para formar relación, que así lo esperan de su justificada y caritativa piedad» (Gomis 2016: 14).

El traspàs d'informació entre la justícia i els cecs o impressors no està analitzat en els territoris de la Corona d'Aragó, però si rastregem els documents d'arxiu sobre els bandolers i els posem en relació amb la versió literària, observem que en molts casos es presenten multitud de coincidències i detalls concrets, com ara la persona que captura al bandit, el que cobra per aquesta acció, la data exacta de la mort o la pena a la qual el condemnen. En el relat del bandit Bord Clua apareix a la perfecció la seua mort en mans del batlle de Tivissa i Llorenç Clua; ${ }^{20}$ en els plecs de Francesc i Miquel Margarit apareix la data exacta de la seua captura i les persones encarregades de l'empresa de persecució, i inclús per la versió literària es podia intuir, confirmada després amb els fons documentals, ${ }^{21}$ que un dels germans va poder escapar del primer setge, però fou capturat poc temps després. ${ }^{22}$ De Mateu Benet es narra la seua anada a Nàpols «amb la dona i els companys» i episodis reals com l'emboscada al carrer d'Alboraia o fins i tot la seua intervenció en el problema de parcialitats entre els Vallterra i els Barrinuevo.

màrtir que entrega la seua vida per amor a Déu. Inclús Pere Armengol, que fou un bandit català del XV que es penedí dels seus actes, acaba morint en mans dels musulmans i anys després fou santificat.

20 Relación de la muerte des Bort Clua Capitan de quadrilla de bandoleros, y otros doze compañeros suyos que tambien murieron a veyente de Julio deste año mil seyscientos y tręe, los quales, fueron muertos por Lloransete Clua y el bayle de Tivissa. Còpia Digital en Bidiso.

21 Arxiu de la Corona d’Aragó (ACA), Consell d’Aragó, lligall 0274, núm.051.

22 Relació verdadera de la mort de Francesch Margarit, y presó de los companyos succebida a tres de mars del any 1627. Composta per Isidro Violer de Moya. Barcelona, Imp.Esteve Liberos 1627. Biblioteca Nacional de Portugal (BNP), F. 2516. Relación verdadera de la muerte de Miguel Margarit cabo de quadrilla y de Valentin Graus su compañero, la una sucedida en 15 de marzo y la otra el 18 del mismo mes, del año 1627. Còpia digital en Bidiso. 
Alejandro Llinares Planells. El final del bandoler: aproximació a la literatura de patíbul de la Corona d'Aragó

En quasi tots els impresos es fa una narració total o parcial de la sentència del bandoler. A continuació compararem algunes versions literàries amb les fonts documentals i la sentència del bandoler, per reafirmar la hipòtesi plantejada. Un exemple el tenim en el cas del valencià Pedro Andrés, conegut com Perot: en un document del Consell d'Aragó es donava les gràcies al virrei per prendre Perot, «cuias crueldades y latrocinios an tenido en nombre en toda España cuya quadrilla ha llegado a penetrar hasta el centro de Castilla, confines de Andalucia, haciendo después mansion en el condado de Concentania y marquesado de Guadaleste y amenaçada y inquita la buena de Gandía». Aquest document confirma la informació del relat, perquè el bandoler literari es presenta com una persona nòmada que desenvolupa les seues accions tant al Regne de València, com a Castella o Andalusia: «De Granada, y de Sevilla/ de Cordova y su comarca/ de Jaen y de otras partes». A més, el document d'arxiu descriu com «lo prendieron en Oteniente», ${ }^{23}$ com també afirma la versió literària. L'imprés de cordell arreplega actes delictius i esdeveniments concrets que li passaren a Perot en Castella, com la persecució de l'alcade de «casa y corte» o l'assassinat d'un metge a la Manxa: «Sin tener alas/ le hize/ a un medico que bolara/ por una burla que hizo/ yo se la tuve guardada», diu el text literari. L'últim esdeveniment esmenat passà en realitat i va tindre una enorme repercussió en Castella, com bé arrepleguen les Cartas de algunos padres de la Compañia de Jesús...:

\begin{abstract}
Lo que hay por acá de nuevo es que ha resucitado Perandrés, ${ }^{24}$ el bandolero, junto á Cuenca, con una brava cuadrilla, y el dicho sabiendo que un médico de dicha ciudad andaba instando y persuadiendo al señor obispo para que procurase remediar los daños que causaba Perandrés y los de su cuadrilla, (....) Fué el médico, y á tres leguas de Cuenca le salieron 40 bandoleros. El hombre, en cuanto hombre, se turbó sobremanera; llegáronse á él, y preguntáronle si era el médico Fulano. Respondió que sí (...) dijo á unas mujeres que venian en su compañía y andaban con ellos, que le trujesen la ayuda que tenia hecha para el señor doctor, y ellas le trujeron una grandisima punta de toro, llena de pólvora, y desnudándole en cueros al pobre médico se la pusieron donde se suelen poner las medicinas, y pegándole fuego le volaron y mataron. Con este género de muerte tan cruel dieron cabo del pobre medico... ${ }^{25}$
\end{abstract}

Al final del plec es reprodueix part de la seua sentència: ${ }^{26}$

23 ACA, Consell d'Aragó, lligall 0724, Núm. 126.

24 A Castella el bandoler era anomenat de diverses maneres, entre elles Perandrés, fet que remarcava la seua condició de catalanoparlant, però també Pedro Andrés, Pere Andrea o inclús Perandrós, per exemple: «Pero també aquel bandolero valenciano que se llama Perandrós ha estado estos dias á cinco leguas de Madrid.»

25 “Cartas de algunos PP. de la compañía de Jesús sobre los sucesos de la Monarquía entre los años de 1634 y 1648 ”, $\checkmark$ Memorial histórico español, Vol.XVII, Madrid, Imprenta Nacional, 1861, p. 408-409.

26 El text del plec de cordell prové del Romance famoso de la vida, prisión, sentencia y muerte de Pedro Andrés. BNE, VE/1446/26. La sentència judicial es trona a l'Arxiu del Regne de València (ARV), Maestre Racional, Tresoreria General. 8.946 (1647), full $25 \mathrm{r}^{\circ}$ (pagament el botxî). 
Alejandro Llinares Planells. El final del bandoler: aproximació a la literatura de patíbul de la Corona d'Aragó

\begin{tabular}{|c|c|}
\hline Plec de cordell & Sentència judicial \\
\hline $\begin{array}{l}\text { Después del cuerpo difunto/ por justa } \\
\text { sentencia manda / que en quarto quartos lo } \\
\text { pongan/ clavados en quatro escarpias. } \\
\text { El verdugo lo executa / Que fue muy buen } \\
\text { camarda [...] Sabado tres de novembre Con } \\
\text { él complir la sentencia / Despues de puestos } \\
\text { en la Raya / Fuero del Portal de Quart Su } \\
\text { cabeza fixada / fuera del portal de quarte. }\end{array}$ & $\begin{array}{l}\text { Fue atormentado, colgado y descuartizado: } \\
\text { su cabeza colocada en el Portal de Quart, un } \\
\text { cuarto en la plaza de Quart, otro cuarto en } \\
\text { la villa de Muro, otro cuarto en la subida de } \\
\text { Agres y otro cuarto en la Venta de Biar, en } \\
\text { la raya de Castilla. }\end{array}$ \\
\hline
\end{tabular}

De la mort de Pedro Andrés s'edità un Pare Nostre el mateix any que expirà el bandoler, que seria repartit entre els assistents a l'execució, i, encara que no aporta molta informació, es deixa clar que el document literari estava pensat per quan «Pedro Andrés estando en el arbol de la justícia para espirar». ${ }^{27}$

El cas de Serrallonga també és bastant il lustratiu, perquè totes les dades que aporten els relats són verídiques (com la desfeta de la seua quadrilla a França, la captura a Santa Coloma, la vida de Joana Massia, etc). Dels quartre impresos contemporanis als bandolers, se n'editaren dos quan el bandit encara estava en presó i tingueren tanta popularitat que en l'obra de teatre, ${ }^{2}$ escrita un any després de la seua mort, el personatge de Serrallonga, quan és capturat, diu: «iantes de prenderme escriben canciones, coplas y versos?», frase interessant, que suggereix l'estreta relació entre la vida dels bandolers i la seua ficcionalització literària. Però la mateixa comèdia aporta informació sobre la possible composició dels relats de cordell, perquè quan el bandoler ja estava en presó, una de les persones que es trobà allí fou «el ciego que vende coplas», i en el moment en què es publicà la sentència del bandoler, el cec va fer callar a tots per escoltar-la i seguidament li va dir a un amic de Joan Sala, que sabia escriure, que li escrigués unes coples sobre ell, "que yo daré dobloncete por el metre». La Relación Verdadera de la vida, robos, y delitós del famoso bandolero Juan Sala, llamada Serrallonga... ${ }^{28}$ conta que el bandoler estava en presó, confessant els seus delictes, i en eixe moment al ludeix a la llargària del procés judicial, que realment conté més de 1000 fulls: «De muertes y robos hechos/ de este forajido/ se halla/ en la Audencia Real/ un proceso de hojas tantas/ que por tomos le dividen / y ay algunos de una quarta.» A més, en els relats compostos després de la seua mort, es fa al lusió a la sentència

27 Elpadre nuestro glossado, que dixo Pedro Andrés estando en el árbol de la justicia para espirar. Con otras dos glosas muy importantes para cualquiera pecador enmendar su vida. BNE VE/154/10.

28 Arxiu Històric de la Ciutat de Barcelona (AHCB), LIB-14 B.

SCRIPTA, Revista internacional de literatura i cultura medieval i moderna, núm. 10/desembre 2017/pp. 108-125 ISSN: 2340 - 4841 doi:10.7203/SCRIPTA.10.11085 
Alejandro Llinares Planells. El final del bandoler: aproximació a la literatura de patíbul de la Corona d'Aragó

del bandoler, que coincideix també amb la judicial: ${ }^{29}$

\begin{tabular}{|c|c|}
\hline Plec de cordell & Sentència judicial \\
\hline $\begin{array}{l}\text { Torturat siga/ ya azotat/ axorallat/ y en el } \\
\text { carrer Regomir atenallat/ prest degollat/ y } \\
\text { fet quartes/ y que despres/ lo seu bell cap/ } \\
\text { tallat com un nap/ sie posat/ clos y tancat/ } \\
\text { en gabieta/ a la torreta/ del portal nou/ de } \\
\text { Sant Antoni. }\end{array}$ & $\begin{array}{l}\text { En aquest dia [8 de gener de l'any } 1634] \text { fou } \\
\text { sentenciat Joan Sala, Serrallonga, natural de } \\
\text { Viladrau, bisbat de vich [...] foch la sentencia } \\
\text { de cent assots, axorellat, aportat ab carretó, } \\
\text { atenallat, y fets quardre quartos, y lo cap } \\
\text { posat en una de les torres del portal de Sant } \\
\text { Antoni de la present ciutat (Reglà i Fuster } \\
\text { 1961: 123) }\end{array}$ \\
\hline
\end{tabular}

També volem comentar el cas de Manuel Manchon, un bandoler de Crevillent de final del segle XVIII, del qual s'escrigué un romanç a principis del XIX. Quan el protagonista fou pres per la justícia civil, se li va obrir un procés inquisitorial per superstició, per una borsa que portava amb «huesecitos y simientes», que li havia donat un gitano per a protegir-se de les bales. El document relata el moment de la captura del bandoler, començant per l'assetjament que li van fer els minyons a les muntanyes. El bandit corregué pel camp «como unos quinientos passos, despues se paro y andando solamente a un paso tirado recibiendo las descargas de los fusileros diciendoles que tirasen que no le ofendian las valas»; tot seguit va entrar a l'ermita de la Romana, «diciendo que bien le podien tirar, que a el no hazian mal las balas, y que de ello se alavaba igualment, despues en la ermita, dando a atender que la virgen le libarava», cosa que va atordir els minyons. Finalment fou capturat per la companyia de fusellers que encapçalava Manuel Beltran, el dugueren a la presó d'Asp i l'amulet que duia va ser cremat. ${ }^{30}$ L'esdeveniment és narrat també en el plec de cordell, pràcticament igual, descrivint que els minyons encapçalats per José Beltran ${ }^{31}$ van disparar amb les escopetes al bandoler i aquest «se acogio a una ermita», afirmant que «viente balas le penetran/ y que ni una herida/ en toda su cuerpo encuentran»: el relat deixa entreveure que això fou obra de la Verge, com el mateix bandoler afirma en el procés inquisitorial, perquè dins l'ermita es posà a resar a la Mare de Déu, perquè «no hay ramera ni ladron/ que su devoción no tenga». Finalment, fou conduit a Asp, i d'allí a València, on fou executat el 13 de desembre de $1779 .^{32}$

29 El text de la sentència judicial el transcrit del Dietari de l'antich consell barceloní.

30 AHN, Inquisició, 3722, Exp. 50.

31 És possible que es canviés el nom de Manuel per José per a reservar la identitat d'aquest.

32 Manuel Manchon, alias el Catalan. Nueva y Curioso Romance, Manuel Manchon, alias el Catalán, Nueva Relación y curioso 
Alejandro Llinares Planells. El final del bandoler: aproximació a la literatura de patíbul de la Corona d'Aragó

Per completar aquesta breu comparativa entre la versió literària i els documents judicials que relaten els últims moments dels bandolers de la Corona d'Aragó, presentarem la sentència judicial i la literària de quatre bandolers més, tots ells amb un imprés editat a principis del XIX, encara que alguns foren bandolers de la segona meitat del XVIII. ${ }^{33}$

\begin{tabular}{|c|c|c|}
\hline Bandoler & Plec de cordell & Sentència judicial \\
\hline $\begin{array}{l}\text { Manuel } \\
\text { Manchon } \\
\text { "El Català" }\end{array}$ & $\begin{array}{l}\text { Fue ahorcado en la Ciudad de Valencia el día } \\
13 \text { diciembre de } 1779 \text { (...) los jueces leyeron/ la } \\
\text { relación per sus delitos/ vista y revisada la causa/ } \\
\text { de que arrestado fuera/ ahorcado fuera/ y su } \\
\text { cuerpo en cuertos/ por los caminos le pusieran/ } \\
\text { la cabeza en Crevillent/ para escarmiento/ la } \\
\text { sentencia leyeron }\end{array}$ & $\begin{array}{l}\text { El día } 11 \text { de diciembre de } 1779 \\
\text { sentencia la justicia a Manuel Manchon } \\
\text { llamado vulgarmente "el català", } \\
\text { natural de Crevillente, a pena de horca, } \\
\text { descuartizado, cortada la cabeza. Y se } \\
\text { ejecutará la sentencia en } 13 \text { de diciembre }\end{array}$ \\
\hline $\begin{array}{l}\text { Francisco } \\
\text { Domingo } \\
\text { "Pigetas" }\end{array}$ & $\begin{array}{l}\text { Manda que sea ahorcado/y descuartizado luego/ } \\
\text { la cabeza en Benafer/ donde cometió arrestos/ } \\
\text { los quartos por los caminos }\end{array}$ & $\begin{array}{l}\text { Señor Fiscal pidió, que pues había } \\
\text { sobrados motivos para "imponerle } \\
\text { la pena ordinaria de muerte de horca } \\
\text { siendo antes arrastrado después hecho } \\
\text { quartos, por resultar cruel homicida } \\
\text { bandolero armado } 6\end{array}$ \\
\hline $\begin{array}{l}\text { Salvador } \\
\text { Moxica }\end{array}$ & $\begin{array}{l}\text { Salvador, desertor igualmente, cercado con su } \\
\text { mujer y cuñado en la Huerta de Orihuela (...) } \\
\text { conducidos a Valencia, y fusilaos por la espalda, } \\
\text { fue descuartizado el Salvador y colocados sus } \\
\text { miembros en diversas partes, tocando su cabeza } \\
\text { a Orihuela, la queda afianzada en la esquina de } \\
\text { la cárcel }\end{array}$ & $\begin{array}{l}\text { 1814-29 de octubre, Salvador Moxica, } \\
\text { desertor del segundo regimiento } \\
\text { de Murcia, fusilado por las armas } \\
\text { por robos en cuadrilla en la zona de } \\
\text { Orihuela." "La cabeza, por mano de } \\
\text { verdugo, fue colocada en los parajes de } \\
\text { Orihuela. (Minguet 1922: 406). }\end{array}$ \\
\hline
\end{tabular}

romance. En que se declaran los arrojos, crueldades y temerarios arrestos de este famoso bandolero, natural de la villa de Crevillente... Biblioteca Història de la Universitat de València, Var. F-72/02.

33 La sentència judicial de Manuel Manchon es troba a l'Arxiu de la confraria de la Mare de Déu dels Desemparats. Llibre de comptes de desemparats i sentenciats (1759-1815), núm. 116., f.36. pel que fa a F. Pigetas, vegeu: Francisco Pigetas, Nuevo y Curioso romance, en que se declaran los arrestos y maldades de Francisco Domingo Flores Pigetas, natural de Benafer, Reino de Valencia; i la seua sentència judicial al Memorial literario, instructivo y curioso de la corte de Madrid, de febrer del 1787, p.160. 
Alejandro Llinares Planells. El final del bandoler: aproximació a la literatura de patíbul de la Corona d'Aragó

\begin{tabular}{|c|c|c|}
\hline $\begin{array}{l}\text { Jaume } \\
\text { Alfonso "el } \\
\text { Barbut" }\end{array}$ & $\begin{array}{l}\text { Jaime el barbudo fue dividido en quadro trozos, } \\
\text { los que fritos en aceite, se pusieran, la cabeza } \\
\text { metida en una jaula de Hierro en la plaza de } \\
\text { Crevillente }\end{array}$ & $\begin{array}{l}\text { Dio muerte en la horca, descuartizó y } \\
\text { frió los cuartos, en que fue condenado } \\
\text { el reo Jayme Alfonso, el barbudo (Soler } \\
\text { 2006: 269). }\end{array}$ \\
\hline
\end{tabular}

\section{Conclusions}

Una de les funcions que tenia la literatura de patíbul era la d'informar a la població dels delictes i del final que li esperava al protagonista de la història i es venia en el mateix acte d'execució del reu. Per aquesta raó, quan la literatura de cordell va ser criminalitzada, al segle XVIII i principis del XIX, perquè era considera incivilitzada per les elits il lustrades (Gomis 2015: 113-130), el jurista, especialitzat en dret penal en temps de Carles III, Manuel de Lardizábal, va plantejar la necessitat de difondre còpies de pregons i de les sentències dels reus per a vendre-les en el mateix acte d'execució del reu, en tant que, per a ell, «causarían en el pueblo efectos harto más saludables que los romances de guapos y valentones llenos de embustes y patrañas que andan publicando los ciegos por las calles» (Tomás y Valiente 1969: 369). Així doncs, les relacions de sentències no tindrien les ambigüitats que els il lustrats retreien als plecs, sinó que serien completament condemnatòries, i per això es consideraven més moralitzants i menys perilloses.

Malgrat la falta d'estudis sobre els relats de patíbul en l'àmbit espanyol, llevant de l'article de Juan Gomis, podem afirmar que, dins de la literatura de cordell, la de bandoler tingué un paper destacat i molts d'aquests impresos jugaren la funció de literatura de patíbul. Com hem pogut veure, es donà un traspàs d'informació entre la justícia i els impressors, i s'hi desenvoluparen uns escrits on es representava el ritual punitiu de la justícia amb una funció noticiera, però, sobretot, moralitzant i propagandística, en mans de les autoritats. Per tant, les execucions públiques foren una part important de la vida quotidiana de la població de l'antic regim i aquestes passaren a la literatura popular perquè, com afirmen Catalá Sanz i Pérez García: «las ejecuciones públicas no solo deben ser consideradas un indicador del rigor punitivo del poder público o un mecanismo de orden y disciplina social. Su escenografía barroca y la sucesión pautada de torturas y suplicios fue también uno de los alimentos de la literatura y del imaginario colectivo (...)» (Catalá \& Pérez 1998:214). 
Alejandro Llinares Planells. El final del bandoler: aproximació a la literatura de patíbul de la Corona d'Aragó

\section{Bibliografia}

AA. DD. (1861)"Cartas de algunos PP. de la compañía de Jesús sobre los sucesos de la Monarquía entre los años de 1634 y 1648”, V Memorial histórico español, Vol.XVII, Madrid, Imprenta Nacional

Aguiló, M. (1900) Cançoner de les obretes en nostra llengua materna més divulgades durant els segles XIV, XV i XVI, Barcelona, Llibreria d'Alvar Verdaguer.

Amades, J. (1995) Els Cent millors romanços catalans, Barcelona.

Andreu, X. (2016) El descubrimiento de España: mito romántico e identidad nacional, Barcelona, Taurus.

Bastien, P.(2006) L'exécution publique à Paris au XVIII e siécle. Una histoire des rituels judiciaries, Paris, Epoques Champ Vallon.

Blecua, J. (1977) Pliegos Poéticos del s. XVI de la Biblioteca de Cataluña, Madrid, Joyas Bibliográficas.

Burke, P. (2005) La cultura popular en la Europa moderna, Madrid, Alianza Universidad.

Catalá, J. \& Pérez, P. (1998) “La pena capital en la Valencia del XVII”, Estudis, 24, p. 203-246.

Civil, P. (1989) "La mort du bandolero à travers les pliegos sueltos des XVIe et XVII e siècles: mise en scène et exemplarité" dins de El bandolerismo y su imagen en el siglo de oro, Madrid, Casa Velázquez, p. $139-151$

Cortés, S. (2007) "De facineroso ladrón a santo milagroso: el culto a los bandidos en la literatura y la devoción popular", Caravelle, 88, p. 11-29.

Davillier, J. (1991) Viaje por España. Tomos I, Madrid, Ediciones.

Foucault, M. (1975) Vigilar y Castigar, Madrid, Siglo Veintiuno.

Fuster, J. (1977) Literatura i llegenda, Barcelona, Edicions 62.

Gilard, C. (2000) "Reyes y bandidos: El arte de morir en el pliego de cordel narrativo", dins de Torrione .M (ed), España Festejante. El siglo XVIII, Málaga, Centro de Ediciones de la Diputación de Málaga, p. 85-94.

Givanel, J. (1945) "Observaciones sugeridas por la lectura del drama de Coello, Royas y Vélez "El Catalan Serrallonga y vandos de Barcelona" en el Butlletí de la Reial Acadèmia de les Bones Lletres de Barcelona , XVIII, 1945, p. 159-192.

Gomis, J. (2016) "Los rostros del criminal: una aproximación a la literatura de patíbulo en España", Cuadernos de Ilustración y Romanticismo: Revista Digital del Grupo de Estudios del Siglo XVIII, 22, p. 9-33.

(2015) "Manzanas de Sodoma. Civilización y cultura popular: entre la contención y la atracción" Historia social, 81, p. 113-130.

(2015) Menudencias de imprenta. La producción y circulación de la literatura popular (València, siglo XVIII), València, Institució Alfons el Magnànim. 
Alejandro Llinares Planells. El final del bandoler: aproximació a la literatura de patíbul de la Corona d'Aragó

Llinares, A. (2017) Bandolers i bandolerismes en la literatura popular de la Corona d'Aragó (ss. XVI-XVIII). Del criminal a l'heroi, València, Universitat de València, Treball de fi de màster inèdit.

Lübebrink, H, (1982) "La literatura del patibolo continuità e transformazioni tra 600 e 800", Quaderni Storici 49 a XVII, 1, p. 284-301.

Massot, J. (1993) Inventari de l'Arxiu de l'Obra del Cançoner Popular de Catalunya, Volum IV, Barcelona, Publicacions de l'Abadia de Montserrat.

Minguet, M. (1922-1923) El general Elio y su tiempo: memoria de los sucesos politicos y militares de España, Vol.1, València, Diario de Valencia.

Nombela, J. (1914) Impresiones y recuerdos, vol III, Madrid, La última moda, 1914.

Reglà, J. i Fuster, J. (1961) Joan Serrallonga : vida i mite del famós bandoler, Barcelona, Aedos.

Salvador, E. (1996) "Tortura y penas en la Valencia foral moderna”, Estudis, 22, p. 263-280.

Soler, E. (2006) Bandoleros: mito y realidad en el romanticismo español, Madrid, Síntesis, 2006.

Tomás y Valiente, F. (1969) El derecho penal de la Monarquía Absoluta ( siglos XVI- XVII- XVIII), Madrid, Tecnos. 